\title{
New data on the taxonomic status and distribution of Gambusia sp. in Croatia and Bosnia and Herzegovina
}

\author{
NEDILJKO LANDEKA ${ }^{1}$ \\ MARTINA PODNAR ${ }^{2}$ \\ DUŠAN JELIĆ ${ }^{*}$ * \\ ${ }^{1}$ Public Health Institute of the Istrian Region \\ Nazorova 23, p.p.192, Pula, Croatia, ddd@zzjziz.hr \\ ${ }^{2}$ Croatian Natural History Museum, Demetrova 1 \\ Zagreb, Croatia, martina.podnar@hpm.hr \\ ${ }^{3 *}$ Croatian Institute for Biodiversity, Lipovac I., no. 7 \\ Zagreb, Croatia, jelic.dusan@gmail.com

\section{${ }^{*}$ Corresponding author:} \\ Dušan Jelić \\ Croatian Institute for Biodiversity, Lipovac I. no. 7 \\ HR-10000 Zagreb \\ e-mail: jelic.dusan@gmail.com
}

Key words: invasive, alien fish, holbrooki, affinis, mitochondrial cytochrome $b$, conservation

Received April 15, 2015.

Revised October 31, 2015.

Accepted November 09, 2015.

\begin{abstract}
Background and Purpose: In the early $20^{\text {th }}$ century, two native North American poeciliid species Gambusia holbrooki and Gambusia affinis were introduced to Europe as a mosquito control agent. The first introduction to Istria from Italy in 1924 was followed by several independent introductions and massive translocations. Presently, the distribution of these two species in Croatia and Bosnia and Herzegovina (Bosnia and Herzegovina) is still largely unknown and they are often confused. The purpose of this study was to determine the taxonomic status of individual Gambusia populations and to shed more light on the distribution and phylogeographic patterns of these invasive species in Croatia and Bosnia and Herzegovina.
\end{abstract}

Materials and Methods: All new and literature data were plotted together to obtain the overall distribution of Gambusia sp. in Croatia and Bosnia and Herzegovina. The samples collected across this range were analysed meristically and by means of mitochondrial cytochrome b (cytb) gene sequence analysis to ascertain the true taxonomic status of the populations. For phylogeographic analysis, the cytb sequences from this study were combined with previously published data.

Results and Conclusions: The methods only confirmed the presence of G. holbrooki. G. holbrooki is continuously distributed across the entire Mediterranean biogeographical region in Croatia and Bosnia and Herzegovina. Two different mitochondrial cytb haplotypes were found: the widely spread Holl haplotype and haplotype Hols that in Europe was previously found only in France and Greece. This suggests that G. holbrooki populations in the region originated from different stocks.

\section{INTRODUCTION}

osquitofish, Gambusia sp., freshwater fish species native to and 1 widely distributed along the Gulf and Atlantic coasts of the United States are currently assigned to two distinct species: Gambusia affinis and G. holbrooki (Gambusia, Poeciliidae). In the course of mosquito and mosquito-borne diseases control efforts they were introduced throughout the world. However, beyond their native range they act as invasive species representing a threat to native biota (1). Their taxonomy has undergone a number of changes in the past including species synonymisation and elevation (2). Briefly, in the mid-19th century, three species were recognised: G. affinis, G. patruelis and G. holbrooki. Shortly after they were considered as a single polytypic species with two subspecies, western one, G. affinis affinis (encompassing former species G. affinis and G. patruelis) and eastern subspecies $G$. affinis holbrooki. However, their 
taxonomic status continued to be questioned. Black and Howell 1979 (3) reported about the existence of reproductive barriers between them, and genetic study of Wooten et al. 1988 (4) based on allozyme analysis, revealed a high degree of genetic divergence as well as the geographical structuring of allele frequencies. Taking all this into consideration, Wooten et al. 1988 (4) have elevated the two subspecies of $G$. affinis, to a species level. These two species have been successfully introduced from North America to most of the warmer parts of the world (2). The distribution of these two species in the areas of introduction is still largely unknown and they are often confused primarily while the most of introductions took place before the last changes in their taxonomy, but also due to the lack or deficiency of historical records about the origins of introduced stocks as well as the complex patterns of their translocation $(2,5)$. The same is true for Croatia and Bosnia and Herzegovina where, until recently, only G. affinis was listed at the official lists of invasive species. Detail analysis, of taxonomic status of Gambusia sp. present in this region, was never conducted.

In Croatian biological and medical literature $(6,7,8$, 9, 10), we find different information on the year of introduction, the type of introduced mosquitofish and the extent of the initial introduction. These data mainly refer to the type of G. affinis, and the period from 1924 to 1932. Prof. Dr. Massimo Sella, biologist, researcher and former director of Office of malaria in Geneva, introduced the first mosquitofishes in Europe. In the 1919/1920 he obtained permission from the Fishery Board USA and the American Red Cross to send mosquitofishes to Italy and Spain, but these fish all died en route. In 1921, the US Agency Fishery Board reiterated the shipment, this time only in Spain (G. holbrooki, from Virginia). Fishes were released into the Estramadure area in antimalarial fight. In a few months, the fishes multiplied rapidly and in the 1922 Ettore Bora, officer of the Association for the Rehabilitation of wetlands, transferred mosquitofishes to Italy. Mosquitofishes ( $G$. holbrooki) were planted in some ponds near the village Colonia Elena.

All Gambusia introduced in Italy belong to the species G. holbrooki (personal collection of AS / DAST 189-1), although some Italian literature indicates the wrong type as G. affinis. The Italians in „Notizi“" from 1927 inform the quote „Initially, we thought that the imported species was G. affinis; but it turned that it was G. holbrooki" (11). This professional misconception has persisted to the present day (12).

Gambusia was introduced in Istria in 1924 from Italy by Gosia and Missirolia from the Directorate General of Public Health, and was planted into a swamp near Poreč for breeding, where in a few months they spread rapidly (12). From this swamp, Gambusia were released in 202 aquatic collection points in the area of Poreč, Rovinj, Pula (13) and on island Krk (14) since they were well adapted to it. Mosquitofish passed through extremely cold winter of $1924 / 25$, with temperatures as low as $-12^{\circ} \mathrm{C}$, despite expert opinions that Gambusia cannot stand northern winters (12). In 1925 from Poreč, Gambusia was introduced to Koper (Slovenia) into a salty bay and canal, with salinity between 25-50\%o. From Italy, mosquitofishes were dispatched to many countries: Germany, Russia, Yugoslavia and Palestine. In Italy they were introduced to all locations with malaria. $G$. holbrooki were significantly spread in many countries on the European continent. In 1926 Dr. Sella conducted another intake of mosquitofish from New York. Ship „President Wilson“ had brought in Trieste 12 consignments with specimens of $G$. patruelis (affinis), significantly more resistant to cold (15). The samples came from hatchery in Illinois (Urbana). These specimens were introduced into a pond near Rovinj and were multiplied during the spring of 1926 . This gives clear indication that $G$. affinis was independently introduced in Croatia just two years after the introduction of $G$. holbrooki 1924. Kottlet and Freyhof 2007 (16) even question whether G. affinis was ever introduced in Europe, because they had no literature evidence of this event. Dr. Sella work clearly indicate that it was introduced in Istria in 1926, but the big question is did it survive or was over competed by $G$. holbrooki.

In August 1924, Dr. Trausmillera, director of Bacteriological station in Kraljevica, brought approximately 400 individuals of mosquitofish ( $G$. holbrooki) on the island of Krk from Istria (Poreč). Mosquitofish are planted in several ponds on the island and in the spring of 1925 Gambusia were moved to 25 new ponds (12). Dr. Sfarčić, director of the Institute for the Study and Control of malaria in Trogir, in April 1924 brought from Spain several specimens of $G$. holbrooki and planted them in a small aquarium of Institute of Trogir where they thrived and increased (12). After that mosquitofish were planted in a pond on island Čiovo, and in ponds of the area of Trogir. Antimalaric Institute of Trogir introduced G. holbrooki in 500 water recipients of the malaria infested area within the jurisdiction of the Institute in Trogir (18). Later, in period 1940-1943, it was alaso widely introduced in Osijek and its surroundings (eastern Croatia) (15). G. holbrooki originating from Virginia (USA) was transferred to Europe by Dr. Sella, then from Italy and Spain, to the Croatian regions of the Adriatic, and then to Bosnia and Herzegovina, Montenegro, Macedonia and Slovenia (12). In an antimalaria campaign, $G$. holbrooki was introduced to 1973 locations (18). In 1997 Peharda and Vrgoč (19) morphologically confirmed the presence of only $G$. holbrooki on island of Čiovo and in ponds in Hrvace (near Sinj). Both of these ponds were repeatedly treated with Gambusia by Sfarčić since 1925 (15). Veenvliet 2007 (20) conducted a similar study in Slovenia and also morphologically confirmed to presence of only $G$. holbrooki. 
European populations of Gambusia were long considered to be $G$. affinis, though the study of Vidal et al. 2010 (5) implied that they actually belong to $G$. holbrooki.

The traditional sister relationship of the $G$. affinis and $G$. holbrooki (affinis species-group) but also species monophyly were previously confirmed by phylogenetic analysis based on the mitochondrial cytochrome $b$ gene (21), providing therefore the frame for genetic species identification. Based on the same molecular marker, the origin and genetic diversity of 24 European populations (from Portugal, Spain, France, Italy, Hungary and Greece) of Gambusia were recently investigated (5). This study revealed only the presence of four different haplotypes (Holl, Hol3, Hol5 and Hol6) for G. holbrooki while G. affinis was not recorded.

The aims of this study were: 1) to contribute to knowledge on distribution of invasive Gambusia sp., 2) the morphological and phylogenetic identification of the Croatian and Bosnian and Herzegovinian populations of Gambusia to determine whether they belong to $G$. affinis or $G$. holbrooki and 3) to obtain insight into phylogeographical structure of Gambusia in this region.

For this purpose, visual morphological determination was performed and the fragment of the mitochondrial cytochrome $b$ gene was sequenced in individuals belonging to Croatian and Bosnian and Herzegovinian Gambusia populations and these were combined with previously published sequences of $G$. affinis and $G$. holbrooki.

\section{MATERIALS AND METHODS}

In this study, the literature data was analysed together with recent data collected from 2000 to 2014. The data was further analysed in ESRI ArcMap v. 10.2.2. software to plot aa distribution map of Gambusia holbrooki in Croatia and Bosnia and Herzegovina. Literature data was collected from following references: Plančić 1948 (22); Tutman 1948 (23); Sabioncello et al. 1964 (24); Morović 1964 (25); Habeković 1967(26); Sabioncello 1967 (27); Morović 1976 (28); Bojčić et al. 1982 (29); Leiner 1984 (30); Treer et al. 1984 (312); Leiner 1985 (32); Tvrtković 1985 (33); Treer 1989 (34); Fašaić et al. 1990 (35); Mrakovčić and Mišetić 1990 (36); Leiner 1993 (37); Vrgoč et al. 1994 (38); Mrakovčić et al. 1995 (39); Maitland and Crivelli 1996 (40); Mrakovčić et al. 1996 (41); Holčik and Mrakovčić 1997 (42); Bonacci et al. 1998 (43); Kerovec et al. 1998 (44); Leiner 1998 (45); Schneider 1998 (46); Mrakovčić et al. 2000 (47); Mikavica et al. 2001 (48); Jakšić et al. 2008 (9); Marguš 2008 (49); Treer

TABLE 1 Individuals molecularly analysed in the present study: geographical origins, sample codes, collection numbers (Tissue collection of the Croatian Natural History Museum), obtained cytochrome b (cytb) haplotypes and GenBank accession numbers. HR=Croatia, BiH = Bosnia and Herzegovina. Detailed geographic information is provided in Appendix 1 and Figure 1.

\begin{tabular}{|c|c|c|c|c|}
\hline Locality & Sample code & Collection number & cytb haplotype & GenBank Acc. No. \\
\hline HR: Sinj, Otok, Karlauša - Sinjsko polje, channels & GKAR-1 & CNHM TC11 & A (HOL1) & KP723566 \\
\hline HR: Poreč, Valkarin pond & GKAR-3 & CNHM TC1644 & A (HOL1) & KP723565 \\
\hline HR: Bale & GKAR-4 & CNHM TC1645 & A (HOL1) & KP723564 \\
\hline HR: Pula, Štinijan & GKAR-5 & CNHM TC1646 & B (HOL5) & KP723559 \\
\hline HR: Rab, Fruga & GKAR-6 & CNHM TC1647 & A (HOL1) & KP723563 \\
\hline HR: Kukuletovica pond & GKAR-84 & CNHM TC1810 & A (HOL1) & KP723569 \\
\hline HR: Marceljani pond & GKAR-72 & CNHM TC1798 & A (HOL1) & KP723570 \\
\hline HR: Pekeci pond & GKAR-59 & CNHM TC1785 & A (HOL1) & KP723571 \\
\hline HR: Grego pond at Bale & GKAR-44 & CNHM TC1770 & A (HOL1) & KP723572 \\
\hline HR: Šalvela pond at Vodnjan & GKAR-26 & CNHM TC1752 & A (HOL1) & KP723573 \\
\hline HR: Galižana-Loborika & GKAR-99 & CNHM TC1825 & B (HOL5) & KP723560 \\
\hline HR: Krk, Vrbnik pond & GKAR-105 & CNHM TC1831 & A (HOL1) & KP723574 \\
\hline BIH: Neretva, Čapljina & GKAR-119 & CNHM TC1929 & A (HOL1) & KP723562 \\
\hline HR: ponds in Majkovi, Dubrovnik & GKAR-121 & CNHM TC1931 & A (HOL1) & KP723567 \\
\hline HR: Vrgorac, Matica & GKAR-122 & CNHM TC1932 & A (HOL1) & KP723568 \\
\hline HR: Čikola, Kljake & GKAR-106 & CNHM TC1832 & A (HOL1) & KP723556 \\
\hline BIH: Trebišnjica, Popovo Polje & GKAR-109 & CNHM TC1835 & A (HOL1) & KP723554 \\
\hline HR: Pag, salt lakes & GKAR-112 & CNHM TC1838 & $\mathrm{B}(\mathrm{HOL} 5)$ & KP723555 \\
\hline HR: Neretva, channels near estuary & GKAR-113 & CNHM TC1839 & A (HOL1) & KP723561 \\
\hline HR: Vransko Lake, channel Prosika & GKAR-117 & CNHM TC1843 & B (HOL5) & KP723557 \\
\hline HR: Mljet, lake in Blato & GKAR-115 & CNHM TC1841 & B (HOL5) & KP723558 \\
\hline
\end{tabular}




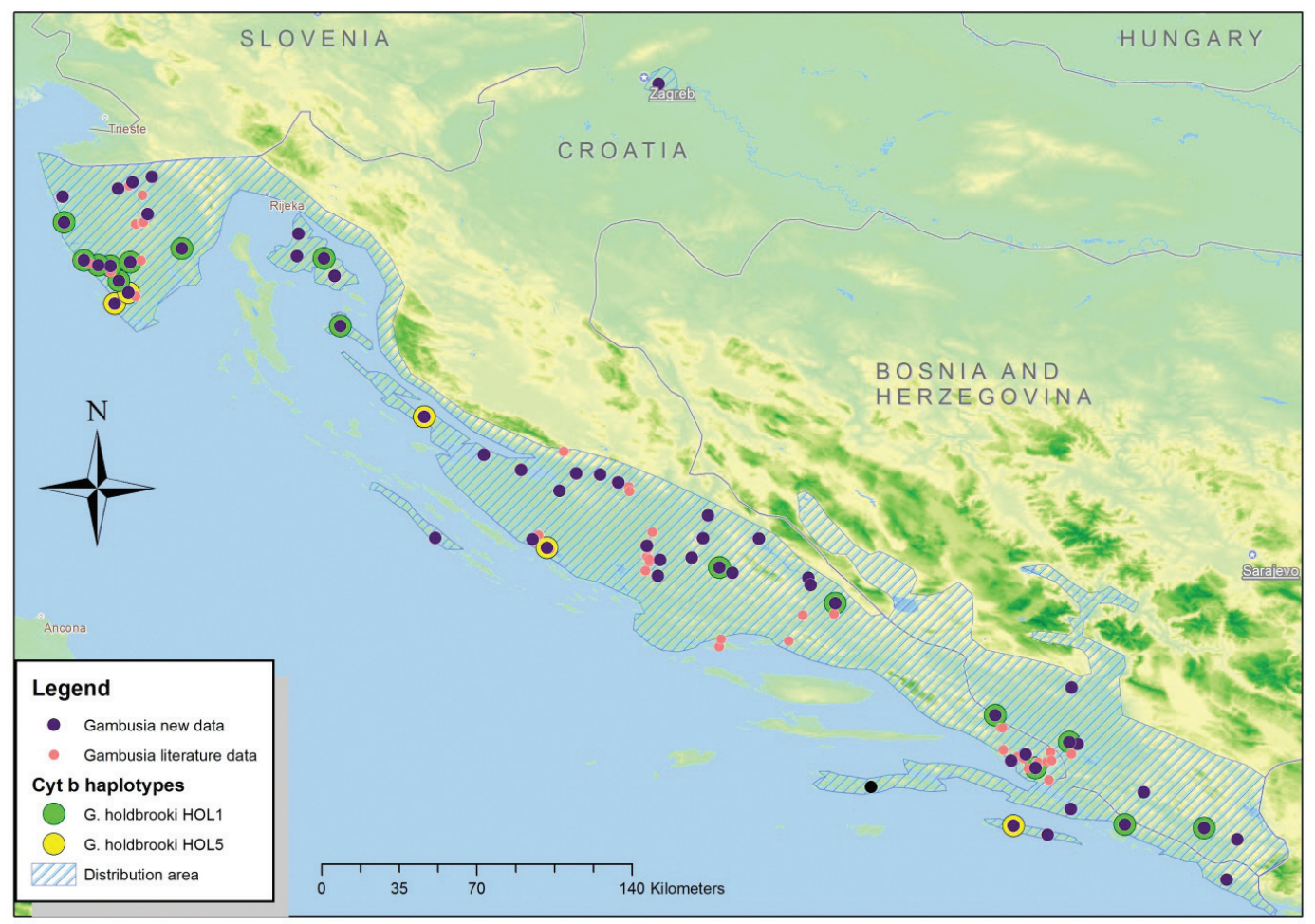

Figure 1. Distribution of Gambusia holbrooki in Croatia and Bosnia and Herzegovina

et al. 2010 (50); Gabelica et al. 2011 (51). A SAMUS $725 \mathrm{M}(\max 1000 \mathrm{~V}, 600 \mathrm{~W})$ electrofishing device and simple hand nets were used for sampling on altogether 63 locations (Appendix 1.). Tissue samples were taken from 21 location (Table 1.) and preserved fish specimens (male, and female) were taken from 10 populations (HR: Sinj, Otok, Karlauša - Sinjsko polje, channels; BIH: Neretva, Čapljina; HR: ponds in Majkovi, Dubrovnik; HR: Vrgorac, Matica; HR: Čikola, Kljake; BIH: Trebišnjica, Popovo Polje; HR: Pag, salt lakes; HR: Neretva, channels near estuary; HR: Vransko Lake, channel Prosika; HR: Mljet, lake in Blato).

For morphological inspection, the gonopodiums of preserved adult male Gambusia was inspected under a digital microscope (AM2111 Dino Lite Basic 20x - 230x) and compared with the illustration by Veenvliet (20) and the description by Rosen and Bailey (52). Morphological measurements were taken from 24 females and 23 males (representing all 10 localities) preserved in 70\% ethanol during field research. This small subset of individuals was selected for inspection due to time consuming process of fixating and photographing the gonopodiums. All individuals were measured for weight, standard body length (SL) and total body length (TL). The number of rays in the dorsal (D) and anal (A) fins was counted according to Kottelat and Freyhof (16). Morphological data collected here is only descriptive and is not intended to be used as general species morphological data.
Total genomic DNA was isolated from the muscle tissue of 21 samples collected in the course of this study from 21 geographic localities (Table 1, Figure 1) using PureLink Genomic DNA Mini Kit (Invitrogen). Although only the single individual per population was analysed, the sampling covered the great part of the Gambusia's range in the investigated area (Figure 1).

For all samples, the mitochondrial DNA fragment spanning from $t R N A_{G l u}$ to $t R N A_{P r o}$ and encompassing the entire cytochrome $b(c y t b)$ gene was amplified by polymerase chain reaction (PCR) using L14725 (5'-GAYTTGAARAACCAYCGTTG-3') and H15982 (5'-CCTAGCTTTGGGAGYTAGG-3') amplification primers (53). The $50 \mu \mathrm{PCR}$ reaction mixture contained 1 x Go Taq ${ }^{\oplus}$ Reaction Buffer (containing $1.5 \mathrm{mM} \mathrm{MgCl}_{2}$, Promega), $0.2 \mathrm{mM}$ of each dNTP, $0.4 \mu \mathrm{M}$ of each primer, 1.25 units of Go Taq ${ }^{\oplus}$ DNA Polymerase (Promega) and approximately $100 \mathrm{ng}$ of genomic DNA. PCR cycling conditions comprised an initial denaturation step $\left(94^{\circ} \mathrm{C}\right.$ for $2 \mathrm{~min}$ ) followed by 35 cycles of denaturation at $94^{\circ}$ for $30 \mathrm{~s}$, annealing at $50^{\circ}$ for $30 \mathrm{~s}$ and elongation at $72^{\circ}$ for $90 \mathrm{~s}$ and a final extension step of $72^{\circ}$ for $7 \mathrm{~min}$.

Sequencing was carried out by Macrogen Inc sequencing service (Seoul, South Korea) using L14725 as a sequencing primer (GenBank Accession Numbers: KP723554-KP723574). The obtained partial cytb sequences were edited and aligned using the BioEdit version 7.2.5 (54) and collapsed to haplotypes using FaBox (55). 
Tree-based species identification of the samples was performed by using three methods of phylogenetic inference: neighbor-joining (NJ), maximum parsimony (MP) and maximum likelihood (ML) as implemented in MEGA version 6 (56). The complete $c y t b$ gene sequences of several Gambusia species were retrieved from the GenBank (GenBank Accession Numbers: KJ696803, EF017514, AP004422, JX679663, JX679662, EF017516, EF017515, EF017518) and aligned with haplotypes obtained in this study. The length of the final alignment was 1019 bp. The cytb sequences of Belonesox belizanus, Girardinus rivasi and Poecila petenensis (GenBank Accession Numbers: JX556410, FJ178707 and KJ696832, respectively) were used as outgroups (57).

For MP analysis, the Tree-Bisection-Reconnection (TBR) algorithm and random addition of sequences (10 replicates) were used. ML analysis was based on the $\mathrm{HKY}+\mathrm{G}$ model which was selected as the best-fit model of sequence evolution under the Bayesian information criterion. For all three methods, the clade support was evaluated by non-parametric bootstrapping (1000, 1000 and 100 pseudoreplicates for NJ, MP and ML, respectively). Additionally, a statistical parsimony network was constructed using TCS software v. 1.13 (58) under a 95\% confidence limit. For this purpose $c y t b$ sequences from this study were aligned with all $G$. holbrooki sequences currently available in the GenBank (Accession Numbers: GHU18210, HM007038, HM443918 and HM443915 - HM443917, HQ609582 - HQ609589, JN565045, JN565047, JN565048 and KJ696803) and trimmed to $304 \mathrm{bp}$ (the length of the shortest sequence). Haplotype frequencies were taken from Vidal et al. (5).

This present study was performed with the authorization of Directorate for Nature Protection, Ministry of Culture (KLASA: UP/I-612-07/10-33/0345, URBROJ: 532-08-0101/3-10-02; KLASA: UP/I-612-0711 0-33/0616, URBROJ: 532-08-01-01/1-10-02; KLASA: UP/I-612-07/10-33/0719, URBROJ: 532-08-01-01/1-10-02).

\section{RESULTS AND DISCUSSION}

\section{Distribution}

Although Gambusia is a very common introduced species, there are surprisingly few literature records. Of the 149 records gathered for Croatia and Bosnia and Herzegovina, 58\% (86) of were retrieved from the recent literature and $42 \%$ (63) were new records gathered by the authors. Distribution area presented in Figure 1 corresponds to the warmer areas close to the Adriatic shoreline. In this areas $G$. holbrooki finds sufficient amount of warm water habitats for reproduction. Only exception is one small population established in Savica Lake in Zagreb, which is a lake used for the discharge of hot water from the Zagreb heat plant. Otherwise they are not found in any of the other surrounding lakes. Gambusia was also wide- ly introduced in Osijek and its surroundings (eastern Croatia) in period 1940-1943, but no literature or recent records of this species are available for anywhere in eastern Croatia. Three introduction events (Italy, 1924; Spain, 1924; USA, 1926) and main translocations known from the literature were summarized in Appendix 2. and compared with present distribution.

This species is still found in all localities in the Adriatic basin (Istria, Dalmatia, Herzegovina) mentioned in literature and also many more. It is obvious that Gambusia holbrooki has advanced capabilities of distribution into new water habitats, in many cases even microhabitats that are not used by other fish species (Mediterranean temporary ponds and swamps). The distribution and habitat preference of Gambusia are similar to those of several native and endemic fish such as Gasterosteus gymnurus, Aphanius fasciatus, Telestes tursky, T. miloradi, Phoxinellus dalmaticus, P. alepidotus, Aulopyge huegelii, Scardinius dergle, etc. To date there has been no systematic research conducted on how this aggressive invader impacts the endemic species communities. On two occasions, the authors accidentally housed $G$. holbrooki with endemic species in a $40 \mathrm{~L}$ tank for 7-12 days, and in both cases, they bit off pieces of caudal and anal fins until the death of the other species. In the first case, three adult females Gambusia killed three subadult Phoxinus lumaireul $(2-4 \mathrm{~cm}$ total body length) and one adult $(-6 \mathrm{~cm})$. In the second case, one adult male and one female $G$. holbrooki killed two juvenile $A$. huegeii $(2-3 \mathrm{~cm})$ and one juvenile $S$. dergle $(-4 \mathrm{~cm})$. All juvenile individuals had the caudal fin completely bitten off, and the adult $P$. lumaireul also had pieces of the anal fin bitten off $(2-3 \mathrm{~mm})$ and it was apparent that the fish died of secondary infections. This kind of Gambusia-caused mortality has already been proven for endangered inanga fish (Galaxias maculatus) in New Zealand (59). In nature, no injured or dead fish were observed, though in several small ponds $(10 \times 15 \mathrm{~m})$ in the bed of the Cikola River near village Kljake (the river usually dries out in June or July), T. tursky and $P$. dalmaticus were found together with a hyperpopulation of $G$. holbrooki in July 2011. Later in August, no individuals of $T$. tursky or $P$. dalmaticus could be found at that site, just $G$. holbrooki. We have no knowledge of other developments that could happen between the two samplings and that would cause these species to disappear. This behaviour should be the subject of more detailed research due to the high number of stenoendemic fish species with a very small distribution are present in the Balkan Peninsula. There is a real danger that they could be pushed into extinction by an advanced invader like Gambusia.

\section{Morphology of inspected individuals}

All 23 inspected males from Croatia and Bosnia and Herzegovina had a gonopodium morphology which corresponds with $G$. holbrooki. In two individuals from 
TABLE 2 Morphological data on G. holbrooki Bosnia and Herzegovina individuals used in this study for gonopodium inspection and fin ray counts. $S L=$ standard body length, $T L=$ total body length. The length measurements are given in millimeters (mm) and weight measurements in $\operatorname{grams}(g)$.

\begin{tabular}{|lcccccc|}
\hline & \multicolumn{3}{c}{ Female } & \multicolumn{3}{c|}{ Male } \\
\cline { 2 - 7 } & $\mathrm{N}$ & Min - Max & Mean \pm SD & N & Min - Max & Mean \pm SD \\
\hline SL & 24 & $18.52-38.79$ & $26.96 \pm 5.852$ & 23 & $17.41-26.76$ & $21.81 \pm 2.416$ \\
TL & 24 & $22.86-47.93$ & $33.41 \pm 7.511$ & 23 & $21.54-31.58$ & $26.86 \pm 2.717$ \\
Weight & 24 & $0.11-1.20$ & $0.43 \pm 0.305$ & 23 & $0.08-0.34$ & $0.17 \pm 0.067$ \\
\hline
\end{tabular}

Neretva River estuary the small spines on the third fin ray were not well visible, though this could be the consequence of preservation in a low ethanol dilution (material started to decompose). The hooks on the posterior branch of the fourth fin ray were relatively large, and compared to illustrations given by Veenvliet (2007) corresponded to $G$. holbrooki morphology. All inspected females had $6^{1 / 2}$ dorsal fin rays and $9^{1 / 2}$ anal fin rays, corresponding to $G$. holbrooki. All except four males had the same number of dorsal and anal fin rays $\left(6^{1 / 2}\right.$ and $9^{1 / 2}$ respectively). One of these males (from Zrmanja River, Kaštel Žegarski) had $5^{1 / 2}$ dorsal fin rays that would correspond to $G$. affinis, but had $9^{1 / 2}$ anal fin rays. Three remaining males had broken dorsal fin so the number of rays could not been counted, but had $9^{1 / 2}$ anal fin rays.

All individuals selected for gonopodium inspection and fin ray counts (anal and dorsal) were adult specimens. Average standard length (SL) for males in our sample was
$21.81 \pm 2.416 \mathrm{~mm}$ and $26.96 \pm 5.852 \mathrm{~mm}$ for females (Table 2). Smallest sexually mature individual was a male with SL of just $17.41 \mathrm{~mm}$, and the largest individual was female with SL of $38.79 \mathrm{~mm}$. Male average weight was $0.17 \pm 0.067 \mathrm{~g}$ and for female this was $0.43 \pm 0.305 \mathrm{~g}$.

\section{Genetic analysis}

Over 1019 bp of the $c y t b$ gene only two different haplotypes, $\mathrm{A}$ and $\mathrm{B}$, differing by a single base substitution, were found (Table 1). In all phylogenetic trees they cluster with $G$. holbrooki sequence with high bootstrap support, proving, therefore, that all analysed samples belong to this species (Figure 2).

GenBank accession numbers are given in parentheses. Haplotypes obtained in this study (corresponding to Holl and Hol5 haplotypes of Vidal et al. (5) across the $309 \mathrm{bp}$ long overlapping region) are depicted in bold. Numbers

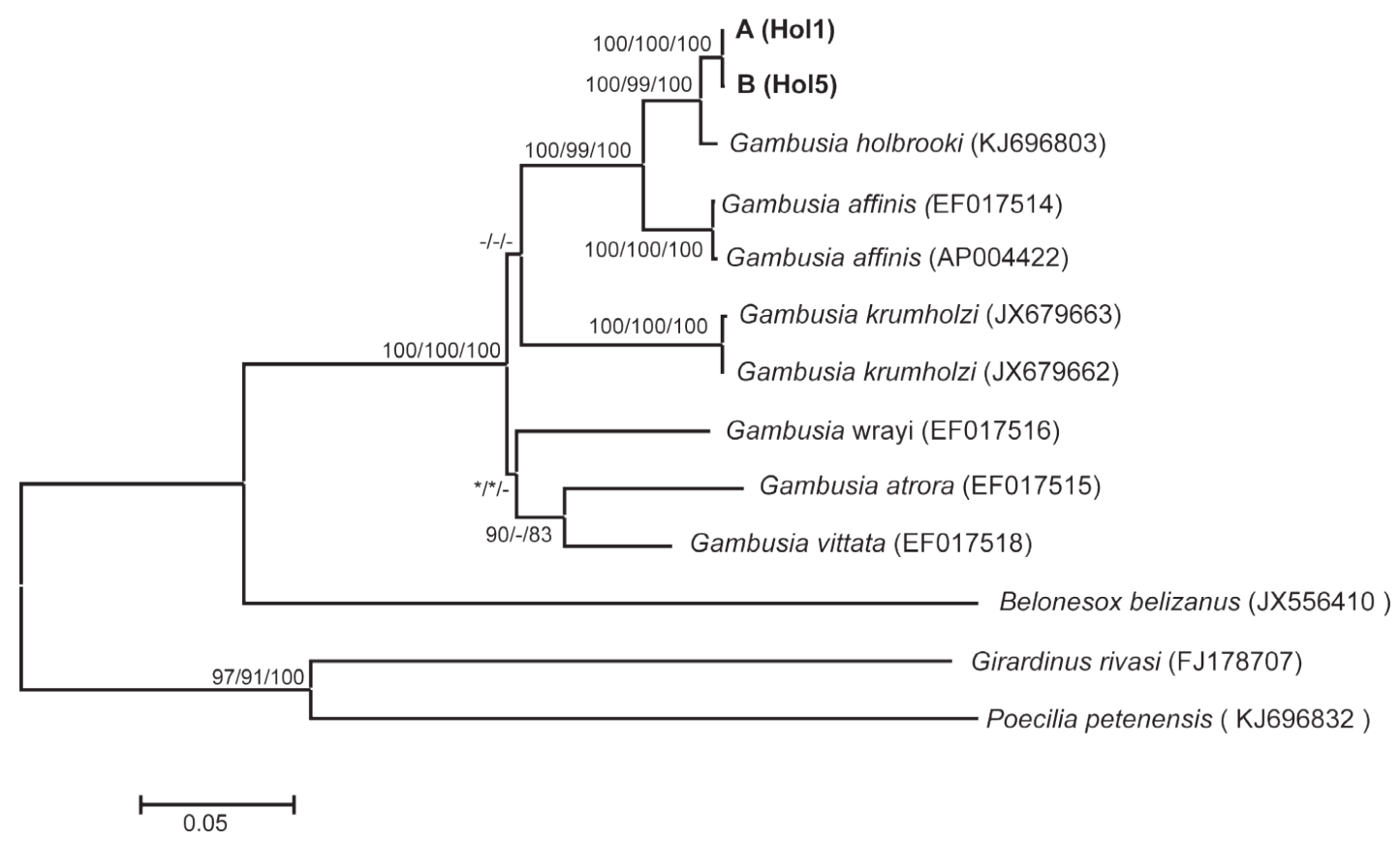

Figure 2. Maximum likelihood phylogram based on 1019 bp long fragment of the mitochondrial cytochrome b showing the relationships between Gambusia specimens from this study and different Gambusia species. 


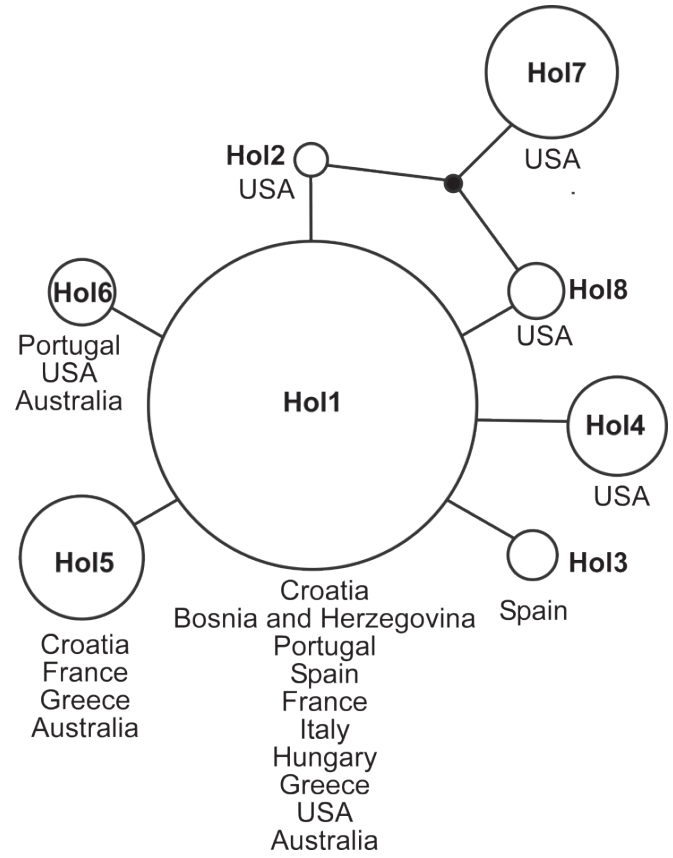

Figure 3. Statistical parsimony network representing the relationships between Gambusia holbrooki cytochrome b haplotypes and their geographic distribution. The sizes of ovals reflect haplotype frequencies. Black dot represent missing intermediate.

by the nodes represent bootstrap (BS) values (neighborjoining/ maximum parsimony/maximum likelihood, respectively). BS values less than 70 are indicated by dash. * $=$ node not obtained

Moreover, across the 309 bp long overlapping region, haplotypes $\mathrm{A}$ and $\mathrm{B}$ observed in this study correspond to Holl and Hol5 haplotypes (5), respectively, which also represent the two most frequent and widespread haplotypes in European populations of $G$. holbrooki (Figure 3). While Holl haplotype was previously found in all investigated European populations with a single exception of one population from France, Hol5 haplotype was recorded for 2 French and 2 Greek populations.

In Croatia, those haplotypes (Holl and Hol5) do not show any regularity in their distribution. The haplotype Hol5 was found in Istria but also on Pag Island and as far away south as at Vransko Lake and Mljet Island. At all other localities haplotypes Holl was found.

Based on the observed distribution pattern they are most probably co-distributed within single populations as it is the case in France and Greece. However, since we analysed only the single individual per population in this study, it need to be confirmed by further investigations.

According to Vidal et al. (5), the presence of Holl and Hol5 haplotypes in European populations of $G$. holbroo$k i$ can be ascribed to the two independent colonization events from the USA: Holl haplotype came in Europe in the course of the first introduction from the USA in Spain from where the fish were further transferred throughout Italy and many other European and Asian countries.

In the second introduction event, the Hol5 haplotype was introduced to France from where (as well as from Italy) the Greece was colonised with $G$. holbrooki (5). The presence of both haplotypes (Holl and Hol5) in the Croatian region closely resembles to the pattern obtained in the Greece (5) and therefore strongly suggests the similar history of introduction.

Although $G$. holbrooki is very adaptable species it is obvious that it did not manage to make stabile populations in continental regions. In spite of intensive breeding and human dispersal, it did not manage to survive in Osijek area and establish natural population. In Zagreb it is only found in parts of Savica lakes where water temperature is increased during winter due to the permanent outflow of hot water from public heating system. This indicates that the cold continental climate in Croatia and Bosnia and Herzegovina is not favourable for overwintering or reproduction of $G$. holbrooki. Our results indicate that $G$. affinis introduced to Rovinj in 1926 (15) did not manage to establish its presence and was probably over dominated by already widespread $G$. holbrooki. This is why, later, it was not introduced to continental areas (Zagreb, Osijek) as G. holbrooki was. G. affinis is significantly more resistant to cold climate and could have been much more serious threat in continental Croatia and Bosnia and Herzegovina, but also central Europe. This species can still be found in pet trade (legal and illegal) and risk of introduction is still very high. All necessary measures should be taken into account to prevent this new invasion. $G$. holbrooki is now widespread in almost all natural and artificial water bodies in Mediterranean part of Croatia and Bosnia and Herzegovina. This species could be classified as one of the worst invasive species because of its variety of translocation vectors, speed of reproduction and direct predation on native fauna (also other fish).

Acknowledgements: Authors would like to thank Petar Žutinić for help during the initial Gambusia measurements. We would also like to thank people who helped in gathering of distribution data and with valuable advices: Mišel Jelic,, Jure Miočić-Stošić, Tea Bašić, Petra Pjevac, Marija Kova= čević, Ivana Sučić, Ivan Špelić, Aljoša Duplić, Josip Bakić i Slavko Brana. We thank two independent reviewers for providing valuable advice and comments.

\section{REFERENCES}

1. COURTENAY Jr. W R, MEFFE G K 1989 Small fishes in strange places: a review of introduced poeciliids. In: Meffe G K and Snelson Jr. F F (eds) Ecology and evolution of livebearing fishes (Poeciliidae). Prentice Hall, Englewood Cliffs, New Jersey, p 319-331

2. PYKE G H 2005 A review of the biology of Gambusia affinis and $G$. holbrooki. Rev Fish Biol Fisher 15: 339-365 http://dx.doi. org/10.1007/s11160-006-6394-x 
3. BLACK D A, HOWELL W M 1979 The North American mosquitofish, Gambusia affinis: A unique case in sex chromosome evolution. Copeia 1979: 509-513 http://dx.doi.org/10.2307/1443231

4. WOOTEN M C, SCRIBNER K T, SMITH M H 1988 Genetic variability and systematics of Gambusia in the southeastern United States. Copeia 1988: 283-289 http://dx.doi.org/10.2307/1445867

5. VIDAL O, GARCIA-BERTHOU E, TEDESCO P A, GARCIAMARIN J-L 2010 Origin and genetic diversity of mosquitofish (Gambusia holbrooki) introduced to Europe. Biol Invasions 12: 841-851 http://dx.doi.org/10.1007/s10530-009-9505-5

6. BAKIĆ J 2000 Organizacija preventivno sanitacijskih postupaka i DDD službe u Hrvatskoj kroz stoljeća (do 1947. godine) [Organisation of preventive and sanitary procedures and DDD service in Croatia through the centuries (until 1947)]. Novine u djelatnosti DDD i ZUPP-a, Poreč, 2000, p 1-14

7. ŠĆETARIĆ V 2002 Biološke metode suzbijanja komaraca - dobrobit ili šteta za prirodu [Biological methods for eradication of mosquitoes - good or bad for nature]. Novine u djelatnosti DDD i ZUPP-a, Poreč, 2002, p 205 - 209

8. MRAKOVČIĆ M, BRIGIĆ A, BUJ I, ĆALETA M, MUSTAFIĆ P, ZANELLA D 2006 Crvena knjiga ugroženih slatkovodnih riba Hrvatske [Red book of freshwater fish of Croatia], Ministarstvo kulture i Državni zavod za zaštitu prirode, Zagreb, p 253

9. JAKŠIĆ Ž, HAMER B, LANDEKA N, BATEL R 2008 Western mosquitofish as a bioindicator of exposure to organochlorine compounds. Ecotoxicol Environ Saf 71: 426-435 http://dx.doi. org/10.1016/j.ecoenv.2007.11.006

10. LUCU Č 2013 Tribute to Professor Massimo Sella - Former Scientist and Director of the Marine Biological Station in Rovinj. 120th Anniversary of marine research in Rovinj (1891-2011) Period Biol 115: 105

11. ANONYMOUS 1927 Introduzione della "Gambusia patruelis" in Italia [Introduction of „Gambusia patruelis“ in Italy]. Riv Malariol 6: 999-1000

12. BAKIĆ J 2006 Vjerodostojne činjenice o prvom medicinskoentomološkom laboratoriju i introdukciji Gambusia holbrooki u Hrvatsku [Trust worthy facts on first medically-entomological laboratory an introduction of Gambusia holbrooki into Croatia]. Hrvatski časopis za javno zdravstvo 2 (6/7), http://www.izlog.info/ tmp/hcjz/sadrzaj.php?broj_casopisa $=6$

13. GIOSEFFI M 1926 Le „Gambusie“ nella lotta antimalarica in Istria [The „Gambusia“ in the fight against malaria in Istria]. Riv Malariol 5: 469-475

14. TRAUSMILLER O 1927 Malarija na otoku Krku. Epidemiologija i pojavljivanje 1923.-1926. [Malaria on the island of Krk. Epidemiology and appearance from 1923-1926]. DNZ Sušak, p 3-54

15. BAKIĆ J 2011 Sedam stoljeća borbe protiv unosa zaraza u Hrvatske krajeve - Osvrt na 60. obljetnicu ustroja suvremene djelatnosti DDD u Hrvata [Seven centuries of the prevention of spreading of the infectious diseases into Croatia - Overview of the 60th anniversary of establishment of modern pest control in Croatia]. Hrvatski časopis za javno zdravstvo 7: 1-24

16. Kottelat, M., Freyhof, J. (2007): Handbook of European Freshwater Fishes. Kottelat, Cornol, Switzerland and Freyhof, Berlin, Germany, p 646

17. ŠKARIĆ, J 1933 Izvještaj o rezultatu desetogodišnjeg rada Higijenskog zavoda u Splitu bivšeg Instituta za malariju (Higijenskog zavoda) u Trogiru i područnih socijalno-medicinskih ustanova u Primorskoj Banovini [Report of results from ten-year work of the Hygiene department in Split, formerly known as Institute for malaria in Trogir and regional socially-medicinal institutions in Primorska Banovina], Split, p 15

18. RADOŠEVIĆ M 2013 Od gambuzija do pariškog zelenila: kako je pobijeđena malarija u Istri [From Gambusia to Paris green: how we defeated malaria in Istria]. Časopis za suvremenu povijest 40: 509530
19. PEHARDA M, VRGOČ N 1997 Species determination, population structure, length/weight relationship, and reproduction characteristics of mosquito fish (Gambusia sp.) at the Čiovo and Hrvace locations. In: Huber Đ (ed) Zbornik sažetaka priopćenja Šestog kongresa biologa Hrvatske, Zagreb. Hrvatsko biološko društvo, Zagreb, p 295

20. VEENVLIET P 2007 Species identity of Gambusia (Pisces: Poeciliidae) introduced to Slovenia. Natura Sloveniae 9: 43-46

21. LYDEARD C, WOOTEN M C, MEYER A 1995 Cytochrome $b$ sequence variation and a molecular phylogeny of the livebearing fish genus Gambusia (Cyprinodontiformes: Poeciliidae). Can J Zool 73: 213-227

22. PLANČIĆ J 1948 Privredni značaj Vranskog jezera [Economic value of Vransko lake]. Ribarstvo Jugoslavije 3: 35-38

23. TUTMAN I 1948 Gambuzija [Gambusia]. Priroda 35: 22-24

24. SABIONCELLO I, MARKO S, HABEKOVIĆ D 1964 Ribarskobiološka ispitivanja Vranskog jezera [Ichthyological and biological research of Vransko lake]. Ribarstvo Jugoslavije 19: 82-94

25. MOROVIĆ D 1964 Vransko jezero [Vransko lake]. Priroda 51: 208-213

26. HABEKOVIĆ D 1967 Eksterijer šarana Vranskog jezera [External characteristics of Vransko lake carp]. Ribarstvo Jugoslavije 22: 96104

27. SABIONCELLO I 1967 Sistematika slatkovodnih riba. Priručnik za slatkovodno ribarstvo [Systematics of freshwater fish. Manual for freshwater fisheries]. In: Livojević Z, Bojčić C (eds) Posebna izdanja „Agronomskog glasnika”. Sveučilište u Zagrebu, Agronomski fakultet, Zagreb, p 90

28. MOROVIĆ D 1976 O mogućnostima razvitka lagunarnog ribarstva u području Stare rijeke (Metković) [On the possibilities to develop lagoon fisheries in the area of Stara Rijeka (Metković)]. Ribarstvo Jugoslavije 31: 6-13

29. BOJČIĆ C, DEBELJAK L, VUKOVIĆ T, JOVANOVIĆKRŠLJANIN B, APOSTOLSKI K, RŽANIČANIN B, TURKM, VOLK S, DRECUN Đ, HABEKOVIĆ D, HRISTIĆ Đ, FIJAN N, PAŽUR K, BUNJEVAC I, MAROŠEVIĆ Đ 1982 Slatkovodno ribarstvo [Freshwater fisheries]. Poslovna zajednica slatkovodnog ribarstva Jugoslavije, Zagreb, p 605

30. LEINER S 1984 Preliminarna istraživanja ihtiofaune kopnenih voda Istre [Preliminary research of the ichthyofauna in mainland Istria]. In: Dizdarević, M. (ed) III. Kongres ekologa Jugoslavije, Sarajevo 24.-30.9.1984. Bilten, Naučni skupovi i savjetovanja knjiga II, serija b, p 37-40

31. TREER T, SAFNER R, RŽANIČANIN B 1984 Komparacija alometrijskog rasta žutalja (Rutilus rubilio, Pisces) na bazi standardne i totalne dužine tijela [Comparative analysis of alometric growth in roach (Rutilus rubilio, Pisces) on the basis of standard and total body length]. Bilten Društva ekologa Bosne i Hercegovine B: 117-120

32. LEINER S 1985 Ihtiofauna kopnenih voda Istre [Ichthyofauna of the mainland waters of Istria]. Magistarski rad, PMF Biološki odsjek, Zagreb.

33. TVRTKOVIĆ N 1985 Ribe Jugoslavije [Fish of Yugoslavia]. Hrvatski narodni zoološki muzej, Zagreb, p 27

34. TREER T 1989 Pregled istraživanja Vranskog jezera kod Biograda na moru [Overview of research on Vransko lake at Biograd na moru]. Morsko ribarstvo 41: 135-138

35. FAŠAIĆ K, MRAKOVČIĆ M, MIŠETIĆ S 1990 Kemizam vode i ihtioprodukcija Visovačkog jezera [Water chemistry and ichthyoproduction of lake Visovac]. In: Kerovec M (ed) Stanje istraženosi i problemi zaštite ekosistema Nacionalnog parka Krka [Overview of research and problematic of ecosystem conservation in Krka national Park]. Ekološke monografije, Knjiga 2., Hrvatsko ekološko društvo, Zagreb, p 365-375 
36. MRAKOVČIĆ M, MIŠETIĆ S 1990 Značaj i karakteristike ihtiofaune rijeke Krke. In: Kerovec M (ed) Stanje istraženosi i problemi zaštite ekosistema Nacionalnog parka Krka [Overview of research and problematic of ecosystem conservation in Krka national Park]. Ekološke monografije, Knjiga 2., Hrvatsko ekološko društvo, Zagreb, p 271-282

37. LEINER S 1993 Područje Cetine i Neretve -150 godina ihtioloških zapisa [Cetina and Neretva River regions - 150 years of ichthyological research]. In: Meštrov M, Erben R (eds) Kongres, Prirodoslovna istraživanja biokovskog područja. Makarska, 11.16.10.1993. Hrvatsko ekološko društvo, Zagreb, p 37.

38. VRGOČ N, ONOFRI I, JUKIĆ S, TONKOVIĆ M 1994 Prilog poznavanju biologije gambuzije (Gambusia affinis Baird i Girardi 1853) stajaćih voda Dalmacije [Contribution to current knowledge of Gambusia (Gambusia affinis Baird i Girardi 1853) biology in Dalmatia]. In: Gomerčić H (ed) Peti Kongres biologa Hrvatske. Hrvatsko biološko društvo, Pula, p 276.

39. MRAKOVČIĆ M, MIŠETIĆ S, POVŽ M 1995 Status of freshwater fish in Croatian Adriatic river systems. Biol Conserv 72: 179-185 http://dx.doi.org/10.1016/0006-3207(94)00080-A

40. MAITLAND P, CRIVELLI A 1996 Conservation of freshwater fish. In: Skinner J, Crivelli A (eds) Conservation of Mediterranean wetlands 7. Tour du Valat Fondation, Arles, p 94

41. MRAKOVČIĆ M, KEROVECM, MIŠETIĆ S, SCHNEIDER D 1996 Description of Knipowitschia punctatissima croatica, (Pisces:Gobiidae), a new freshwater goby from Dalmatia, Croatia. In: Kirchhofer A, Hefti D (eds) Conservation of endangered freshwater fish in Europe. Advaces in life sciences, Basel, p 311-319 http:// dx.doi.org/10.1007/978-3-0348-9014-4_31

42. HOLČIK J, MRAKOVČIĆ M 1997 First record of Lethenteron zanandreai (Cyclostomata, Petromyzontidae) in the Adriatic basin of the Balkan peninsula and its zoogeographic consequences. Folia Zool 46: 263-271

43. BONACCI O, KEROVEC $\mathrm{M}$, ROJE-BONACCI T, MRAKOVČIĆ M, PLENKOVIĆ-MORAJ A 1998 Ecologically acceptable flows definition for the Žrnovnica River (Croatia). Regulated rivers: Research \& Management 14: 245-256 http://dx.doi. org/10.1002/(SICI)1099-1646(199805/06)14:3<245::AIDRRR491>3.0.CO;2-7

44. KEROVEC M, MRAKOVČIĆ M, SCHNEIDER D, TOMAŠKOVIĆ N 1998 Occurrence of Chondrostoma phoxinus in Croatia. Folia Zool 47: 39-43

45. LEINER S 1998 Rijeka Odra u Turopolju: Zaštita staništa i biološke raznolikosti Turopoljskog luga [River Odra in Turopolje: Habitat protection and biological diversity of Turopolje forest]. Rezultati druge godine bioloških istraživanja, Zoološki odjel HPM, Zagreb.

46. SCHNEIDER D 1998 Taksonomske i biološke značajke populacije vijuna Cobitis taenia (Pisces, Cobitidae) delte Neretve [Taxonomic and biological characteristics of Cobitis taenia (Pisces, Cobitidae) from Neretva delta]. PhD thesis, University of Zagreb, Zagreb, p 113

\section{Appendix 1.}

New data on distribution of $G$. holbrooki in Croatia and Bosnia and Herzegovina ( $\mathrm{N}$ and $\mathrm{E}$ coordinates, in WGS84; presented as decimal degrees; UTM (10x10 $\mathrm{km})$ ). The data are presented in Figure 1.

Konavle, ponds and channels, 42,5507, 18,3253, BN81; Trebinje, 42,7133, 18,3679, BN83; Mljet, lake in
47. MRAKOVČIĆ M, SCHNEIDER D, MIŠETIĆ S, ŠURMANOVIĆ D 2000 Ihtiofauna Baćinskih jezera [Ichthyofauna of Baćina lakes]. Ekološke monografije 5, Biokovo 2: 203-212

48. MIKAVICA D, MUHAMEDAGIĆ S, DIZDAREVIĆ F, SAVIĆ N 2001 Idioecological characteristics of Adriatic trout Salmothymus obtusirostris oxyrhynchus (Steindachner, 1882). Symposium of livestock production with international participation, Struga, Republic of Macedonia

49. MARGUŠ D 2008 Skradinski buk [Skradin waterfalls]. Hrvatska vodoprivreda 183: 33-39

50. TREER T, MATULIĆ D, BOGDANOVIĆ G, ANIČIĆ I, SAFNER R, PIRIA M, ŠPREM N, TOMLJENOVIĆ T 2010 The condition of allochtonous fishes in the Mediterranean Vransko Lake. J Appl Ichthyol 27: 965-967 http://dx.doi.org/10.1111/ j.1439-0426.2010.01610.x

51. GABELICA I, PIASEVOLI G, JURIĆ M, MEKINIĆ S, KAŽIMIR Z, PEŠIĆ N, PERKOVIĆ A 2011 Zaštićene prirodne vrijednosti splitsko-dalmatinske županije [Protected natural values in Split-Dalmatia county]. Javna ustanova za upravljanje zaštićenim prirodnim vrijednostima na području splitsko-dalmatinske županije, Split, p 130

52. ROSEN D E, BAILEY R M 1963 The poeciliid fishes (Cyprinodontiformes), their structure, zoogeography, and systematics. Bull Am Mus Nat Hist NY 126: 1-176

53. HRBEK T, STOLTING K N, BARDAKCI F, KUCUK F, WILDEKAMP R H, MEYER A 2004 Plate tectonics and biogeographical patterns of the Pseudophoxinus (Pisces: Cypriniformes) species complex of central Anatolia, Turkey. Mol Phylogenet Evol 32: 297-308

54. HALL T A 1999 BioEdit: a user-friendly biological sequence alignment editor and analysis program for Windows 96/98/NT. Nucleic Acids Symp Ser 4: 95-98

55. VILLESEN P 2007 Fabox: an online toolbox for fasta sequences. Mol Ecol Notes 7: 965-968 http://dx.doi. org/10.1111/j.1471-8286.2007.01821.x

56. TAMURA K, STECHER G, PETERSON D, FILIPSKI A, KUMAR S 2013 MEGA6: Molecular Evolutionary Genetics Analysis version 6.0. Mol Biol Evol 30: 2725-2729 http://dx.doi.org/10.1093/ molbev/mst197

57. HRBEK T, SECKINGER J, MEYER A 2007 A phylogenetic and biogeographic perspective on the evolution of poeciliid fishes. Mol Phylogenet Evol 43: 986-998 http://dx.doi.org/10.1016/j.ympev.2006.06.009

58. CLEMENT M, POSADA D, CRANDALL KA 2000 TCS: a computer program to estimate gene genealogies. Mol Ecol 9: 1657-1660 http://dx.doi.org/10.1046/j.1365-294x.2000.01020.x

59. BAKER C, ROWE D, SMITH J 2004 Gambusia: a biodiversity threat? Water \& Atmosphere 12: 1-3
Sobra, 42,7319, 17,6005, YH13; Trebišnjica, Popovo polje, 42,7591, 18,2346, BN73; Mljet, lake in Blato, 42,7680, 17,4618, YH03; ponds in Majkovi, Dubrovnik, 42,7735, 17,9120, YH33; Gorni Majkovi, two ponds, $42,7735,17,9120, \mathrm{YH} 33$; Ston, channels in village, 42,8368, 17,6942, YH24; Popovo polje, Trebišnjica, 
42,9040, 17,9901, YH45; Korčula, Smokvica, 42,9350, 16,8820, YH06; Neretva, channels near estuary, 43,0030, 17,5511, XH96; Neretva estuary, 43,0322, 17,4519, YH07; Neretva, Modro oko, 43,0575, 17,5104, YH27; Bregava, Neretva, 43,0997, 17,7214, YH17; Neretva, Čapljina, 43,1077, 17,6874, XH98; Vrgorac, Matica, 43,2170, 17,3880, YJ10; Mostarsko blato, channel, 43,3292, 17,6966, XJ43; Sinj, Otok, Karlauša - Sinjsko polje, channels, 43,6716, 16,7388, XJ34; Rumin, channel near Cetina, 43,7753, 16,6299, XJ34; pond in Konjevrate, Krka, 43,7818, 16,0194, WJ84; Čikola, Čavoglave, 43,7945, 16,3216, XJ04; Čikola, Kljake, 43,8157, 16,2684, XJ05; pond in Ključ, Krka, 43,8465, 16,0290, WJ85; Čikola, Drniš, 43,8555, 16,1569, WJ95; Vransko jezero, channel Prosika, 43,8966, 15,5694, WJ46; Krka, Roški waterfall, 43,9034, 15,9753, WJ76; Vransko jezero, near ornithological station, 43,9301, 15,5117, WJ46; Vinalić, channels in the valley (Cetina), 43,9335, 16,4289, XJ16; River in Uzdolje (Knin), 43,9349, 16,2034, WJ96; Telašćica, pond near Sv. Ante church, 43,9366, 15,1175, WJ06; Krka, Šarena jezera in Knin, 44,0265, 16,2224, WJ97; Karin, Ravni Kotari, 44,1273, 15,6210, WJ48; Kaštel Žegarski, upstream from the bridge, 44,1608,
15,8596, WJ69; Zrmanja, Kaštel Žegarski, 44,1624, 15,8561, WJ69; Zrmanja, Berberi, 44,1931, 15,7859, WJ69; Zrmanja, Obrovac, 44,1988, 15,6879, WJ59; Brestica, Posedarje, 44,2114, 15,4648, WJ39; Jaruga, Miočići, Stošići, 44,2738, 15,3147, WK20; Pag, salt lakes, 44,4282, 15,0715, WK01; Rab, Fruga,44,0331, 14,7463, VK76; Pula, Štinijan, 44,8873, 13,8164, VK07; GaližanaLoborika, 44,9315, 13,8729, VK17; Šalvela pond at Vodnjan, 44,9798, 13,8332, VK08; Krk, Ričina, Baška, 44,9996, 14,7091, VK78; Bale, 45,0398, 13,8005, VK08; Grego pond at Bale, 45,0431, 13,7511, VK08; Pekeci pond, 45,0541, 13,8797, VK18; Kukuletovica pond, 45,0622, 13,6917, UK99; Krk, Vrbnik pond, 45,0702, 14,6655, VK79; Krk, lake Ponikve at Malinska, 45,0788, 14,5567, VK69; Marceljani pond, 45,1099, 14,0898, VK29; Jezero at Njivice, 45,1698, 14,5620, VL60; Poreč, Valkarin pond,45,2057, 13,6446, UL90; Pazinčica, 45,2507, 13,9505, VL11; Mirna, estuary, 45,3210, 13,6050, UL91; Mirna, Stara Mirna at Livade, 45,3536, 13,8301, VL02; Istarske Toplice, Mirna, 45,3796, 13,8895, VL12; Mirna, Buzet, 45,4014, 13,9680, VL12; Savica, Zagreb, 45,7793, 16,0226, WL77.

\section{Appendix 2.}

Map of three main introduction routes for Gambusia sp. and main known translocations routes from 1924 until 1943 within research area.

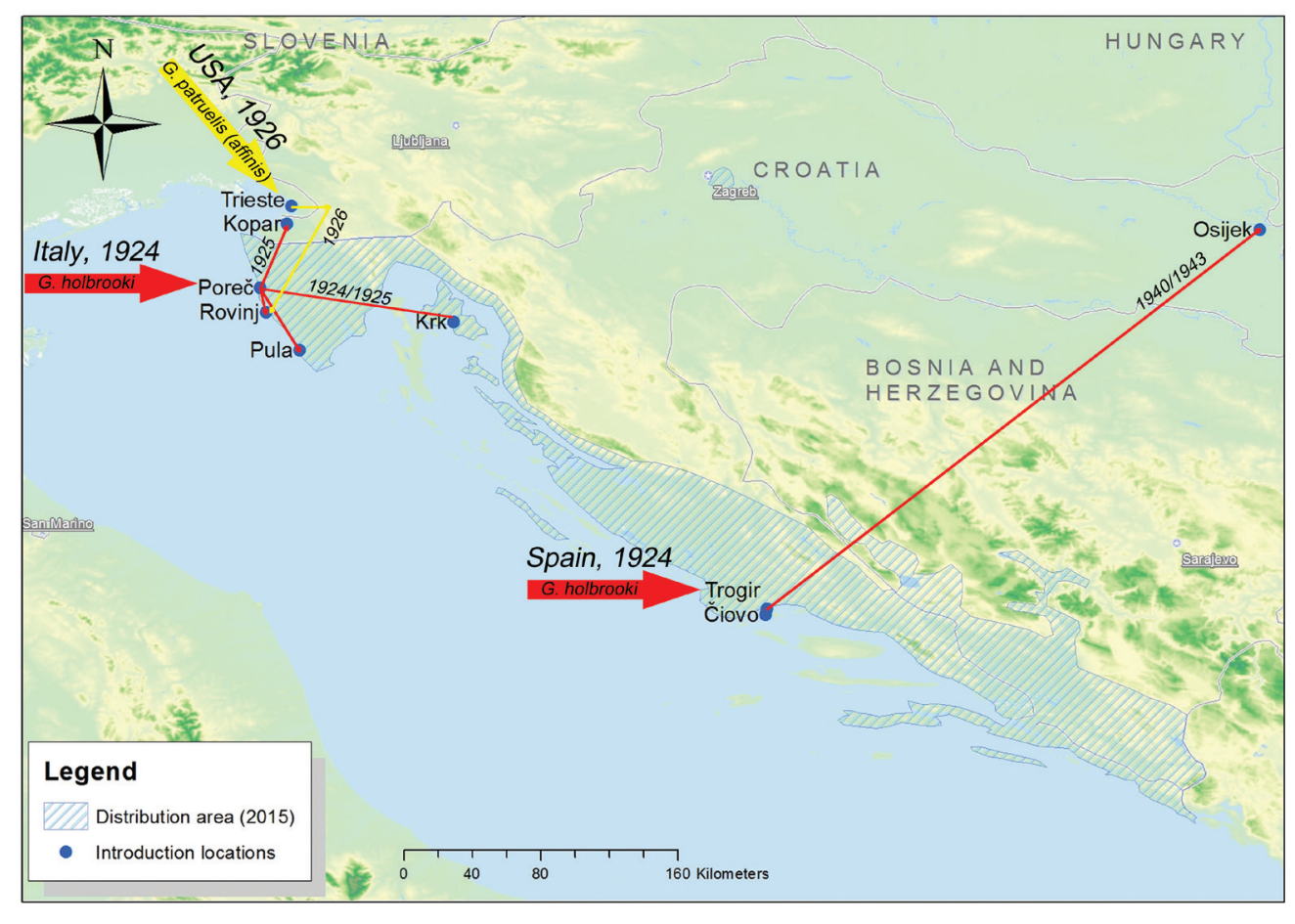

